\title{
'Dil kirliliğini engelle Türkçe kelimeleri tercih et' konulu soysal sorumluluk afiş tasarımları
}

\section{Çağrı GÜMÜŞı}

\begin{abstract}
APA: Gümüş, Ç. (2020). 'Dil kirliliğini engelle Türkçe kelimeleri tercih et' konulu soysal sorumluluk afiș tasarımları. RumeliDE Dil ve Edebiyat Araştırmaları Dergisi, (19), 192-203. DOI: 10.29000/rumelide. 752269 .
\end{abstract}

\section{$\ddot{\mathbf{O} z}$}

Çalışmanın amacı, "Dil Kirliliğini Engelle, Türkçe Kelimeleri Tercih Et” sloganı ile tasarlanan afiş tasarımlarıyla hedef kitleyi bilinçlendirmektir. $\mathrm{Bu}$ araştırmada nicel araştırma yöntemi uygulanmaktadır. Model olarak da tarama modelinden yararlanılmıştır. Araştırmanın ilk bölümünde 19 - 25 yaş aralığında 317 özel üniversite öğrencisine eş zamanlı olarak günlük hayatta en sık karşılaşılan 20 tane İngilizce ve Türkçe kelime anket formu aracılığıyla verilerek konuşma dilinde hangisini tercih ettikleri sorulmuştur. Anketten elde edilen bilgiler doğrultusunda, afiş tasarımlarının hazırlanması amacıyla 2 öğretim elemanı, 1 eğitim uzmanı, 1 metin yazarı, 1 iletişim uzmanı 2 grafik tasarımı uzmanından oluşan bir uzman grup oluşturulmuştur. Bir sosyal sorumluluk olarak “Dil Kirliliğini Engelle, Türkçe Kelimeleri Tercih Et” çalışması, içerik ağırlıklı bir çalışma olarak ele alınmıştır. Çalışmada, "mesajını çok açık bir biçimde ortaya koyan, problemi ve çözümü birlikte sunan bir slogan yapısı” tercih edilmiştir. Seri bir afiş çalışması olarak kurgulanan çalışma için özenle seçilen içerikler, tipografiye taşınmıştır. Çalışmanın ana özelliği içeriklerin güçlü bir şekilde görsele taşınmasıdır. Bu çalışma için günlük hayatta en sık karşılaşılan yabancı kelime kullanımı dikkate alınmış ve problemi doğrudan yansıtan 20 adet afiş tasarlanmıştır. Araştırmacı tarafından tasarlanan afiş tasarımları uzman gruba gösterilmiş ve onların görüşleri doğrultusunda düzeltilerek tasarım tamamlanmıştır. Yabancı kelimelerin yerli yersiz kullanımı dil kirliliğine neden olmaktadır. Özenli bir Türkçe kullanımı, bu kirliliği engelleyecektir. Buradaki sorun, dil kirliliği, Türkçe kelimelerin tercih edilmesi ise sorunun çözümüdür.

Anahtar kelimeler: Sosyal sorumluluk, dil kirliliği, afiş tasarımı

\section{Social responsibility poster designs on 'Prevent language pollution, prefer Turkish words'}

\begin{abstract}
The aim of the study is to raise awareness of the target audience with the poster designs projected with the slogan "prevent language pollution, prefer Turkish words".Quantitative research method is applied in this research. The screening model has also been used as a Model. Turkish and English words, which are most common in daily life, were given to 317 private university students in the 19 - 25 age range simultaneously and asked which ones they preferred in the colloquial language by means of the questionnaire. In line with the information obtained from the survey, an expert group consisting of 2 instructors, 1 educational expert, 1 copywriter, 1 communication expert, 2 graphic design experts has been formed in order to prepare poster designs.As a social responsibility, the study "prevent language pollution, prefer Turkish words" was taken as a content-oriented study. In
\end{abstract}

1 Doç. Dr., KTO Karatay Üniversitesi, Güzel Sanatlar ve Tasarım Fakültesi, Grafik Tasarım Bölümü (Konya, Türkiye), cagrigumus79@gmail.com, ORCID ID: 0000-0001-5901-9708 [Makale kaylt tarihi: 30.04.2020-kabul tarihi: 20.06.2020; DOI: 10.29000/rumelide.752269] 


\begin{abstract}
the study, "a slogan structure that reveals its message very clearly and presents the problem and the solution together" was preferred. Carefully selected contents for the work, which was fictionalized as a serial poster work, were carried into typography. The main feature of the work is the strong movement of the contents into the visual. For this study, the most common use of foreign words in daily life was taken into account and 20 posters were designed to directly reflect the problem. The poster designs projected by the researcher were shown to the expert group and the design was completed by correcting them according to their opinions.In season and out of season use of foreign words causes language pollution. Careful use of Turkish will prevent this pollution. The problem here is language pollution and the choice of Turkish words is the solution to this problem.
\end{abstract}

Keywords: Social responsibility, language pollution, poster design

\title{
Giriş
}

Dünyadaki bütün toplumların kültürünü yansıtan ve kuşaktan kuşağa aktarılmasına aracılık eden, toplumların birbirlerinden farklılaşmasını sağlayan, bir bütünlük içinde onları belirli bir yığın olmaktan kurtaran dil; her toplumun yaşama ve ayakta kalma nedenidir. Çünkü her şey dil ile var olmaktadır. Dil bir insanın doğumundan itibaren ait olduğu toplumda yaşamasını, o toplumun kültürünü tanıyarak buna göre hayatını idame ettirmesini, insanın yaşadığı toplumdaki diğer insanlarla ilişki kurabilmesini sağlayan yegâne araçtır. Günümüzde sosyal yaşamda iletişim kurabilmek için önemli bir yere sahip olan dil; küresellikten, sosyal ve kültürel faktörlerden, siyaset, bilim ve teknolojik gelişme ve değişimlerden oldukça etkilenmektedir. Ayrıca, insanların yaşadığı toplumdaki kuşak farlılıkları da o toplumda kullanılan dile olan bakış açılarını değiştirmektedir. (Şenyuva E., Ertüzün F., Turhan K. ve Demir N., 2017:1384).

Dilin tanımı, işlevi, milletler için önemi hakkında şu ana kadar çok şey söylenmiştir. Dil hakkında söylenen bütün sözleri bir araya getirdiğimizde şu genel tespite ulaşmak mümkündür: Dil, dünyayı değiştiren bir güçtür; hem bir zenginliktir hem de mirastır. Taşıdığı bu önemli özellikler, dili "korunması gereken bir unsur" hâline getirmektedir. Kültür değişimi ve bu değişime bağlı olarak ortaya çıkan yabancı etkiler, dil üzerindeki en önemli tehditlerden biridir. Türkçe, günümüzde kadar "yabancı etki” tehdidiyle birçok kez karşılaşmıştır. Bir dili, yabancı dillere karşı koruyacak en önemli unsurların başında dil bilinci ve dil bilgisi gelir. Diline sahip çıkan ve dilini kurallara uygun olarak kullanan bireyler, o dilin koruyucusu olmaktadır. Dilimize son yıllarda -Türkçe karşıllğı olmasına rağmen- birçok yabancı kelime girmesinden ve sosyal medyadaki dil kullanımından yola çıkarak diyebiliriz ki Türk toplumundaki dil bilinci, maalesef her geçen gün azalmaktadır (Balyemez, 2016:5).

Ana dil, çocuğu yetiştiren kişiler olan en başta anne ve babadan daha sonrasında ise yakın çevresinin vasıtasıyla öğrendiği ve artık çocuğun ya da bireyin özü olan, kendisini tanımlayıp açıklayabildiği dildir. Birey dili, anne, baba, kardeş, akraba, arkadaşları ve öğretmeniyle temas ederek; doğduktan sonra öğrendiği konuşma yeteneği ile dili iletişim aracı olarak şekillendirmeye ve kullanmaya başlamaktadır. Birey dili konuşmaya başladığında kendisine şu soruyu sorması gerekmektedir. " Ben ana dilimi doğru bir şekilde kullanabiliyor muyum?”. Şu anda ana dilini kullanan bir bireyin bu soruya vereceği cevap "hayır" olmaktadır. Çünkü, evet ana dil kullanılmakta ancak ana dil kullanılırken gerekli olan özen gösterilmemektedir. Günümüzde bireylerin ana dili kullanma şekillerine bakıldığında; bireylerde olması gereken dil bilincinin gelişmediğini, dilin yabancı sözcüklerle kirletildiği ve kirlenmenin sonucunda toplumdaki her bireyin dile ilişkin yanlışları tekrar tekrar yaptığı söylenebilir (Şuataman, 2013:408). 
Yaşadığımız toplumda gazete, dergi televizyon vb. kitle iletişim araçlarında kullanılan Türkçenin kurallarına dikkat edilmeden kullanıldığı herkes tarafından bilinmektedir. Kitle iletişim araçlarının kullanılmaya başlamasıyla birlikte Türkçenin kuralları ile kullanılmasına ilişkin çeşitli önlemler alınmış olsa da bu kurallar ne medya da ne de bu medya da çalışan kişiler tarafından ciddiye alınmıştır. Bu araçlarda yabancı kökenli Türkçeleşmiş kelimelerin kullanımı sıklaşmış, diğer dillerden yapılan çeviriler sonucunda bu dillerden gelen deyimler ve kavramlar günlük konuşma dilinde kullanılmaya başlanmıştır. Burada yaşanan değişim, dilin yozlaşmasına neden olmuştur. Bu konu dilin kullanımına karşı duyarlı olan birçok kişi tarafından açıkça dile getirilmiştir (Gülbuğ, 2007:579).

Kitle iletişim araçlarında yazılan ya da ekranda gösterilen bilgilerin doğru Türkçe kullanılmadan anlatılması toplumsal ve kültürel yaşamı olumsuz etkilemektedir. Televizyon, radyo, kitap, gazete ya da dergide dil bilgisi kurallarına uyulmadan yayın/yayım yapıldığı zaman, bu kitle iletişim araçlarını kullanan izleyiciler, dinleyiciler ve okuyucular iletilmek istenenleri yanlış algılayabilirler. Bu yanlış algılamaları ya da anlamaları engelleyebilmek için bu araçlarda dilbilgisi kurallarına kesinlikle uyulması, izleyici, dinleyici ve okuyucunun bu kurallara uyması ortaya çıkacak olan anlam karmaşası ve belirsizliğinin giderilmesi gerekmektedir. Aynı dili konuşan ve yazan bireyler birbirleriyle bu kurallara uymak için birlik oldukları zaman doğru iletişim kurabilirler. Burada dil kullanımının kurallara bağlı olduğunu ve kurallara göre sınırlandırıldığı söylenebilir. (Gökdayı, 2008:97).

Günümüzde dergi, gazete, televizyon ve radyo gibi kitle iletişim araçlarında Türkçe dil bilgisi kurallarına uyulmadan yayın ve yayım yapıldığı görülmektedir. Özellikle özel yayıncılı̆̆a başlanmasıyla birlikte Türk dilinin doğru kullanılmasına ilişkin alınan önlemler ne medya da ne de medya çalışanları tarafından benimsenmektedir. Diğer dillerden Türkçeye geçen yabancı sözcükler rahatsız edici şekilde kullanılmakta, yabancı kaynaklardan Türkçeye çeviriler dikkat edilmeden yapılmasının sonucunda Türkçeye birçok deyim ve sözcük yerleşmektedir. Bu sorun Tük diline duyarlı birçok yazar ve akademisyen tarafından dile getirilmektedir. Burada söylenen şey, gün geçtikçe yukarıda sıralanan sebeplerden dolayı Türk dilinin giderek yozlaştı̆̆ıdır. Dilde anlatılmak istenen yozlaşma kavramı, dilin değişime uğradığını bu değişime neden olan kişilerin düşünce ve tutumlarını anlatmaktadır (Gülbuğ, 2007:579).

Sosyal sorumluluk kavramını bir araya getiren "sorumluluk ve sosyal" kelimelerinin sözlük de karşılığı toplumsal ve toplumla ilgili anlamında tanımlanırken, sorumluluk kelimesi ise bireyin kendisinin ya da başkalarının yapmış olduğu davranış ve tutumlarından dolayı bir başka bireye ya da yetkiliye karşı sorumlu olma olarak tanımlanabilir (Yönet, 2005:241). Bireysel sorumluluklar, zamanla değişip, büyüyerek sosyal sorumluluğun odak noktasını oluştururlar.

"Tasarım, hayalde canlandırılan bir olayın projesi, çizimi veya üç boyutlu görüntüsü olarak uygulanan ve ortaya konulan eserlerin tümüne verilen isimdir" (Tepecik, 2002:27). Tasarım kavramının değeri bulunduğumuz çağda daha iyi anlaşılmış olsa da tarihsel sürece bakıldığında bireylerin dünyayı algılama biçimlerini ve toplumsal, ekonomik siyasi dönüşüm ve değişime etkisi olan önemli bir terim olarak karşımıza çıkmaktadır (Çitci, 2009: 27). Tasarımın önemli mecralarından biri olan afiş tasarımı, bir ürün ya da hizmet ile ilgili verilecek mesajların hedef kitleye ulaşmasında önemli bir yere sahiptir. Özellikle kitle iletişim araçları olan televizyon, dergi, gazete açık hava ve radyo ile entegre edildiği zaman büyük etkiler yaratmaktadır. Çünkü, bir grafik tasarım ürünü olan afişler görüntünün ve yazının bir arada bütüncül bir şekilde verildiği ve hedef kitlenin özellikle dışarıda her an karşısına çlkabilecek bir araçtır (Hollis, 2005:11). Afiş, hedef kitleye verilmek istenen mesajı dikkati çekerek, kolayca anlaşllabilecek bir şekilde aktaran bir iletişim sürecine sahiptir (Mazlum, 2006: 170). 
Teknolojinin kendi terimleriyle hızlı bir şekilde hayatımıza girişi, yabancı dillerden dilimize geçen kelimeler ve buna bir de özensizlik eklenince Türkçemizin mercek altına alınması kaçınılmaz bir hâle gelmiştir. Türkçenin doğru ve özenli kullanımı için bireysel ve kurumsal anlamda sorumluluk almak gerekmektedir. Yabancı kelimelerden arındırılmış duru bir Türkçe, toplumun bütün kesimlerini ilgilendirmektedir. Bu anlamda öncelikle dili görünür şekilde kullanan ve yayan reklam şirketleri, marka sahipleri, akademisyen ve bilişim uzmanları başta olmak üzere herkes bu toplumsal konuda sorumluluk taşımaktadır. Çevre, göç, yoksullukla mücadele, şiddet, daha iyi iş, daha iyi eğitim, sürdürülebilir kalkınma, enerji tasarrufu, yeşil enerji alkol istismarı, sağlık sorunları, trafik kazaları (Alver, 2019:623) gibi pek çok konu başlığı bir sosyal sorumluluk afişlerinin içini doldurabilir.

Yabancı dilin olumsuz etkilerinin günlük hayatımızda yansımalarının konu edinildiği çalışmalar (Demircan, 2001; Kartallığlu, 2001; Danac1, 2005; Kaya, 2008; Küçük \& Saraç, 2008; Üstünova vd. 2010, Arvas, 2011; Gaddar, 2014; Mert \& Türkmen, 2014; Yaman \& Ekmekçi, 2016) genellikle işyeri isimleri üzerine yoğunlaşmıştır. Bu çalışmalarda yabancı dillerin, özellikle İngilizcenin, şehirlerde işyeri isimlerinde ne denli olumsuz etkilerinin olduğunu örneklerle gözler önüne serilmektedir (Ekmekçi v.d., 2017). Ayrıca, Ay tarafından yazılan "Türkçedeki Yabancılaşmanın Önlenebilmesini Amaçlayan Sosyal İçerikli Afiş Tasarımları" isimli makale bu konuya dikkat çekmektedir. Ay çalışmasında "Türkçedeki yabancılaşmaya dikkat çekilmesi ve bu doğrultuda sosyal içerikli afiş tasarımlarının üretilmesi yoluyla Türkçedeki yabancılaşmanın önlenebilmesine yönelik yapılan çalışmalara katkı sağlanması amaçlamıştır. Ayrıca araştırmanın amacına uygun olarak, farklı tasarımcılar tarafından yapılan benzer amaçlı afiş tasarımlarını inceleyerek yorumlamıştır." (Ay, 2016:502).

Türkçe'nin özenli kullanımı hep göz ardı edilen bir konu olmuştur. Bu soruna dikkat çekmek isterken mecra olarak afişi seçmek, kampanyaların ana materyali olan afiş ile göz ardı edileni göz önüne sermek üzere bir tercihi de göstermektedir.

\section{Araştırmanın amacı}

Bu araştırmanın temel amacı; "Dil Kirliğini Engelle Türkçe Kelimeleri Tercih Et" sloganı kullanılarak yapılan afiş tasarımlarıyla hedef kitleyi bu konuda bilinçlendirmektedir.

\section{Araştırmanın yöntemi}

Araştırmanın deseni, bu çalışmada nicel araştırma yöntemi uygulanmaktadır. Model olarak da tarama modelinden yararlanılmıştır. Tarama modelinde bilimin gözleme kaydetme, olaylar arasındaki ilişkileri tespit etme, kontrol edilen değişmez ilişkiler üzerinde genellemelere varma vardır.

Araştırmanın evrenini 19-25 yaş aralığında 317 özel üniversite öğrencisi oluşturmaktadır. Araştırmanın örneklemi ise tasarımı yapılan 20 adet afiştir.

Ölçme aracı ve verilerin toplanması, 19 - 25 yaş aralığında 317 özel üniversite öğrencisine eş zamanlı olarak günlük hayatta en sık karşılaşılan 20 adet İngilizce ve Türkçe kelime anket formu aracıllğıyla verilerek konuşma dilinde hangisini tercih ettikleri sorulmuştur. Anketten elde edilen bilgiler doğrultusunda, afiş tasarımlarının hazırlanması amacıyla 2 öğretim elemanı, 1 eğitim uzmanı, 1 metin yazarı, 1 iletişim uzmanı 2 grafik tasarımı uzmanından oluşan bir uzman grup oluşturulmuştur. Öncelikle dil kirliliği ile ilgili strateji (amaç, problem tanımlandı ve hedef kitle belirlendi) ve yaratıcı strateji (slogan ve hedef kitleye verilecek mesajlar hazırlandı) geliştirilmiştir. 
Bir sosyal sorumluluk olarak "Dil Kirliliğini Engelle, Türkçe Kelimeleri Tercih Et” çalışması, içerik ağırlıklı bir çalışma olarak ele alınmıştır. Çalışmada, "mesajını çok açık bir biçimde ortaya koyan, problemi ve çözümü birlikte sunan bir slogan yapısı" tercih edilmiştir. Seri bir afiş çalışması olarak kurgulanan çalışma için özenle seçilen içerikler, tipografiye taşınmıştır. Çalışmanın ana özelliği içeriklerin güçlü bir şekilde görsele taşınmasıdır.

$\mathrm{Bu}$ çalışma için günlük hayatta en sık karşılaşılan yabancı kelime kullanımı dikkate alınmış ve problemi doğrudan yansıtan 20 adet afiş tasarlanmıştır. Araştırmacı tarafından tasarlanan afiş̧ tasarımları uzman gruba gösterilmiş ve onların görüşleri doğrultusunda düzeltilerek tasarım tamamlanmıştır.

Verilerin çözümlenmesi, anket yoluyla elde edilen verilerin çözümü için SPSS istatistik programı kullanılmıştır. Elde edilen veriler doğrultusunda yüzde, frekans tablosu hazırlanmış ve yorumlanmıştır. Araştırmada elde edilen veriler SPSS programına işlenerek, verilerin analizinde ulaşılmak istenen bulguya göre frekans ve yüzde, teknikleri kullanılmıştır.

\section{Bulgular ve yorum}

Araştırmada seçilen kelimeler günlük konuşma dilinde birbirlerinin yerine kullanılmaktadır. Tercih edilen her iki kelimede aynı anlama gelse de burada dikkat edilmesi gereken konu bu kelimelerin her yerde Türkçesinin kullanılmasıdır. Bu doğrultuda gönüllü katılımcılara uygulanan anketin sonuçları ve ankette yer alan kelimeler tablo 1'de verilmiştir.

Tablo 1. Araştırmaya katılanların kelime seçimi konusundaki frekans dağılımı.

\begin{tabular}{cccc}
\hline Yabancı Kelime & (\%) f & Türkçe Kelime & (\%) f \\
\hline Absürt & 87.8 & Saçma & 12.2 \\
Aktüel & 1.6 & Güncel & 98.4 \\
Buton & 37.3 & Düğme & 62.7 \\
Center & 6.5 & Merkez & 93.5 \\
Dizayn & 22.8 & Tasarım & 77.2 \\
Konsept & 55.9 & Kavram & 44.1 \\
Optimist & 7.1 & İyimser & 92.9 \\
Realite & 23.5 & Gerçeklik & 76.5 \\
Mega & 22.3 & Çok Büyük & 77.7 \\
Grammer & 31.9 & Dil Bilgisi & 68.1 \\
Editör & 72.5 & Yayımcı & 27.5 \\
Chat & 62.8 & Sanal Sohbet & 37.2 \\
Egoist & 52.1 & Bencil & 47.9 \\
Gala & 73.9 & Ön Gösterim & 26.1 \\
Marjinal & 45.3 & Sira Dişı & 54.7 \\
Network & 56 & Bilişim Ă̆ı & 44 \\
Revizyon & 27.2 & Düzeltme & 72.8 \\
Senkron & 28.3 & Eş Zaman & 71.7
\end{tabular}




\begin{tabular}{llcr} 
Defans & 39.9 & Savunma & 29.9 \\
Doping & 70.1 & Uyarıcı & 29.9 \\
\hline
\end{tabular}

Tablo 1'e göre, katılımcıların \%87.8'si günlük konuşma dilinde "saçma" kelimesini tercih ederken \%12.2'si "absürt" kelimesini tercih etmişlerdir. Katılımcıların büyük bir kısmı "güncel kelimesini tercih ederken çok az bir kısmı ise "aktüel" kelimesini tercih etmiştir. Yine katılımcıların \%37.3'ü "buton" kelimesini tercih ederken \%62.7'si “düğme” kelimesini tercih etmiştir. Katılımclların büyük bir çoğunluğu "merkez" kelimesini seçerken, çok az bir kısmı ise "center" kelimesini tercih etmiştir. Katılımcların \%77.2'si "tasarım" kelimesini \%22.8'si dizayn kelimesini kullanmayı tercih etmektedir. Yine katılımclların \%55.9'u "konsept kelimesini \%44,1'i "kavram" kelimesini kullanmayı tercih etmektedir. Katılımclların \%7.1'i "optimist" kelimesini \%92.9'u ise "iyimser" kelimesini tercih etmektedir. Ayrıca katılımcıların \%23.5” "realite" kelimesini tercih ederken \%76.5” ise "gerçeklik" kelimesini tercih etmektedir. Yine katılımcların \%31.9'u "grammer" kelimesini \%68.1'i "dil bilgisi" kelimesini tercih etmektedir. Katılımcıların \%22.3'ü "mega kelimesini \%77.7'si "çok büyük” kelimesini tercih etmiştir. Katılımcıların \%27.5’i "yayımcı" kelimesini \%72.5’i ise "editör” kelimesini tercih etmiştir. Katılımcıların \%62.8'i "chat" kelimesini \%37.2'si ise "sanal sohbet” kelimesini tercih etmiştir. Katılımclların \%52.1”i "egoist” kelimesini \%47.9'u ise bencil kelimesini tercih ettiğini söylemektedir. Yine katılımcıların \%73.9'u "gala" kelimesini tercih ederken \%26.1'i "ön gösterim" kelimesini tercih etmiştir. Katılımcıların \%54.7'si "sıra dışı" kelimesini \%45.3’ü ise "marjinal” kelimesini tercih etmiştir. Katılımcıların \%56'sı "network" kelimesini \%44'ü ise "bilişim ağı" kelimesini tercih etmiştir. Katılımcların \%72.8’i düzeltme kelimesini \%27.2'si ise "revizyon" kelimesini tercih ettiklerini söylemiş̧ir. Yine katılımcıların \%28.3'ü "senkron" kelimesini \&71.7'si ise "eş zaman" kelimesini tercih etmiştir. Katılımclların \%60.1'i savunma kelimesini tercih ederken \%39.9'u ise "defans" kelimesini tercih etmiştir. Son olarak katılımcıların \%29.9'u "uyarıcı" kelimesini tercih ederken \%70.1'i “doping” kelimesini tercih ettiklerini söylemiştir.

Ayrıca anketin sonunda isteğe bağlı olarak kişisel görüş ve önerilerini belirtmeleri istenilen açı uçlu bölümde dile getirilen 11 yorum içerisinde, "Ya kendimi çok Türkçe bilmez gibi hissettim. Keşke böyle olmasaydı"; "Bazı İngilizce kökenli kelimeler çok kuvvetli olabiliyor. Örneğin egoist=bencil. Bence egoist bencilden daha güçlü bir itham. Bu nedenle insanların kullanımı buna göre değissebileceğini düşünüyorum"; "Kelimelerin evrensel formları daha güzel geliyor"; "Dilini kaybeden, diline sahip çıkmayan bir ulus kültürünü, birlik ve beraberliğini ardından bağımsızlığını yitirir... Bu bilinçle yoluna devam eden gençler asıl ben teşekkür ederim sizlere...”; “Kavram ve Konsept sözcükleri TDK tarafından eş anlamlı olarak kabul edilse de günlük yaşamda birbirinden çok farklı anlamları var (Türk Dil Kurumu Sözlükleri, 2020). Ben ikisini de kullanıyorum. İyi çalışmalar"; Türkçe dilinde konuşuyorsak tamamen Türkçe kelimeler kullanalım. Ne gerek var arada yabancı dilde kelimeler kullanmaya"; "Bunların aynı anlama geldiğini bilmeyen çok fazla kişi var. Kulağımıza sürekli yabancı kökenli kelimeler geldiğinde o kelimelere alışıyoruz. Ancak o kadar güzel Türkçeleri varken duymuyoruz. Dolayısıyla, az kullanıyoruz. Bu kelimeleri ankete dahil ettiğiniz için teşekkürler”; Türkçe öğretmeniyim ve böyle bir çalışma hazırladığınız için çok teşekkür ederim" "bu tür çalışmaların çoğalması ve çocuklara yönelik olması dileğiyle"; "Yaşasın var olsun Türk Dili"; "Ne kadar yabancı kelime kullanıyormuşuz" ifadeleri bu yönde yapılmış bir çalışmaya ihtiyaç duyulduğunu ve bunun takdir edildiğini göstermektedir. Geriye kalan yorumlar ise teşekkür ve çalışmaya başarı dilekleri şeklindedir.

Anket çalışması sonunda tasarlanan afiş tasarımları üç aşamada analiz edilmiştir. Görseller Ekı'de yer almaktadır. 


\section{Görsel}

Afiş tasarımında ilk bakıldığında büyük puntolarla, siyah renkte ve kalın olarak yazılmış Türkçe kelimeler görülmektedir. Yanında ise aynı büyüklük ve özelliklerde gri ile yazılmış ve üzeri çizilmiş yabancı dillerden Türkçemize giren ve aynı anlama gelen ikinci bir kelime verilmiştir.

Yan yana yazılmış bu iki kelimenin altında mesaj yer almaktadır: "Dil Kirliliğini Engelle, Türkçe Kelimeleri Tercih Et” Ana mesajın hemen altında ise Türkçenin güzelliğini ve anlam zenginliğini vurgulamak için seçilen kelimenin kök yapısı belirtilmiş, kelimenin Türkçe karşllğı bilgi olarak verilmiştir. Zeminde pastel ve suluboya özellikle dikkatin öndeki yazıya verilmesi için tercih edilmiştir.

Görsel bize şu mesajları vermektedir: Kelimenin dilimize girmiş yabancı kökenli karşılı̆̆ı var, kullanıyoruz ama kullanmak yanlş. Çünkü bu yanlışlar Türkçemizi kirletiyor. Sen Türkçe olanı tercih edersen, dil kirliliğini de engellemiş olursun. Yapacağın tek şey Türkçe olanı tercih etmek...

\section{Metin}

Metinler, görselde kullanılan ve afişe konu olan ana kelimenin kısa açıklaması şeklinde çalışılmıştır. Bu açıklama slogan ile desteklenmiştir. Görseli oluşturan ana kelime, bu kelimenin kısa açılklaması ve slogan olmak üzere 3 parçalı bir metin çalışması bulunmaktadır. Örneğin;

Ana Kelime: güncel (aktüel)

Açıklama: güncel (sıfat) Günün konusu olan, şimdiki, bugünkü (haber, olay vb.) "Güncel olaylar, yorumlarla şaşılacak bir özdeşlik, bir uyum gösterir.”-N. Cumah Slogan: "Dil Kirliliğini Engelle, Türkçe Kelimeleri Tercih Et”

Ana Kelime: düğme (buton)

Açıklama: düğme (isim) Bazı aletleri çalıştırmaya yarayan "Gözlerimle aradım, zil düğmesine benzer bir şey de göremedim.”-A.Gündüz

Slogan: "Dil Kirliliğini Engelle, Türkçe Kelimeleri Tercih Et"

\section{Slogan}

"Dil Kirliliğini Engelle, Türkçe Kelimeleri Tercih Et” Çalışmada, “mesajını çok açık bir biçimde ortaya koyan, problemi ve çözümü birlikte sunan bir slogan yapısı" tercih edilmiştir. Sorun: Dil kirliliği

Sorun Eylemi: Dil kirliliğini engelle

Çözüm: Türkçe kelimeleri tercih etmek

Çözüm Eylemi: Türkçe kelimeleri tercih et

Yabancı kelimelerin yerli yersiz kullanımı dil kirliliğine neden olmaktadır. Özenli bir Türkçe kullanımı, bu kirliliği engelleyecektir. Buradaki sorun, dil kirliliği, Türkçe kelimelerin tercih edilmesi ise sorunun çözümüdür. 


\section{Sonuç ve öneriler}

Tüm dünyada dillerin amacı daha belirgin bir durumdadır. Tüm diller ferdî ve millî açıdan gün geçtikçe daha önemli bir hâle gelmektedir. Günümüzde, bir bireyin hangi millete ait olduğu noktasında ana dili belirleyici olmaktadır. Bu doğrultuda Türk milletine ait olmanın en önemli göstergelerinden birisi Türkçe konuşmaktır. Türkçe konuşan bireyler, Türk milletine aittir. Türkçe de Türk milletinin dilidir.

Tüm dünyada olduğu gibi, dili öğrenmenin ve öğretebilmenin en kolay yolu eğitimdir. Bireyler dilini ilk olarak anne babadan öğrenirken asıl dili tüm incelikleriyle okulda öğrenmektedir. Hangi alandan olursa olsun her eğitimcinin en önemli görevlerinden birisi ana dilimiz olan Türkçeye karşı öğrencilerin duyarlı davranmalarını sağlamak ve her ne olursa olsun Türkçe kelimeleri kullanmalarına teşvik etmektir. Bu doğrultuda, ana dilimiz Türkçenin doğru öğrenilmesi hem öğrencilerin başarılı olmasını sağlayacak hem de toplumun gelişmesine katkı sağlayacaktır.

Bulgulardan elde edilen sonuçlara göre katılımcıların çoğunun günlük konuşma dilinde Türkçe kelimeleri kullandıkları görülmüştür. 20 adet kelimeden yalnızca 6 adet kelimede (kavram yerine konsept, yayımcı yerine editör, sanal sohbet yerine chat, bencil yerine egoist, gösterim yerine gala ve uyarıcı yerine doping) yabancı sözcükleri tercih etmişlerdir.

Bu çalışmadan çıkarılacak diğer bir sonuç, ana dilimiz olan Türkçeyi yabancı kelimelerden arındırmak, yabancı kelime kullanımını en aza indirgemek ve tasarlanan afişleri görmesi beklenen hedef kitlenin dil kirliliği konusunda bilinçlenip hem günlük hem de mesleki hayatında yabancı kelimeler yerine Türkçe kelimeleri tercih etmesini sağlamaktır.

\section{Bu bağlamda şu önerilerde bulunulabilir:}

- Ortaöğretim ve Yükseköğretim kurumlarında bu konularla ilgili seminer, konferanslar verilmeli ve bu tarz çalışmalar farklı uygulamalarla geliştirilmelidir.

- Dil kirliliğini önlemeye yönelik olarak Türkçe yayın sayısının artırılmasını sağlanmalı ve bu konuda daha çok araştırılma yapılmasına ön ayak olunmalıdır.

- Dil kirliliği dışında anadilimiz olan Türkçenin doğru bir biçimde kullanılmasına ilişkin çalışmalar ve tasarımlar yapılması sağlanmalıdır.

\section{Kaynakça}

Alver, E. (2019). Üniversite Öğrencilerinin Alkol İstismarının Depresyon Düzeyleri ile İlişkisi Üzerine Bir İnceleme, Journal of Academic Value Studies, (5 )4, 623-638.

Ay, R. (2016). Türkçedeki Yabancılaşmanın Önlenebilmesini Amaçlayăn Sosyal İçerikli Afiş Tasarımları, Dumlupınar Üniversitesi Sosyal Bilimler Dergisi, Avrasya Özel Sayı, 501-510.

Balyemez, S. (2016). Dil Bilgisi Üzerine Açıklamalar. Ankara: Pegem Akademi.

Çitçi E. (2009). Görsel Kültür Elemanı Olarak 20.yy'da Afişin Toplumsal Süreçlere Etkisi. Çukurova Üniversitesi Sosyal Bilimler Enstitüsü Resim-İş Eğitimi Ana Bilim Dalı Yüksek Lisans Tezi. Adana.

Dili. Sosyal ve Beşeri Bilimler Dergisi, 5(2), 1309-8012. 
Ekmekçi, E., Yaman, İ., Şahin, M. (2017). Diller Arası Etkileşimin Bir Sonucu Olarak Dil Kirliliğ̈i:Türkiye'deki İkinci El Araç İlanlari Örneği, $1^{\text {st }}$ International Black Sea Conference on Language and Language Education, September 22-23.

Gökdayı, H. (2008). Dil Kullanımını Değerlendirmede Doğru ve Yanlış. Erdem Dergisi, (51), 91-109.

Gülbuğ E. (2007). Kitle İletişim Araçlarında Kullanılan Türkçe ve Yozlaşan Bir Değer Olarak Dil Üzerine. 38. ICANAS Atatürk Kültür Dil ve Tarih Yüksek Kurumu, 569-590.

Güllüdağ, N., (2012). Yazılı ve Görsel Basında Dil Estetiği. 21. Yüzyılda Eğitim ve Toplum Dergisi, I (1), 49-58.

Türk Dil Kurumu Sözlükler. (2020). Erişim Adresi: https://sozluk.gov.tr/

Hollis, R. (2005), Graphic Design A Concise History, London: Thames \&Hudson.

Mazlum, F. S. (2006). Masaüstü Yayıncılık. Ankara: Gazi Kitabevi.

Şenyuva, E., Ertüzün, F., Turhan, K ve Demir, N. (2017). Türk Diline İlişkin Sorunlar, Çözüm Önerileri ve Türkçe Bilinci: Kuşaklararası Karşılaştırma. Uluslararası Türkçe Edebiyat Kültür Eğitim Dergisi, 6(3), 1384-1397.

Şuataman, Ö. (2013). Ana Dili Kullanımına Verilen Önem: Basın-Yayında Türk

Dili. Sosyal ve Beşeri Bilimler Dergisi, 5(2), 1309-8012.

Tepecik, A. (2002). Grafik Sanatlar Tarih - Tasarım - Teknoloji. Ankara: Detay.

Yönet, E. (2006). Kurumsal Sosyal Sorumluluk Anlayışında Son Dönemeç, Balıkesir Üniversitesi Sosyal Bilimler Dergisi, 13, 239-264. 


\section{Ek 1: Afişs Tasarımları}




202 / RumeliDE Journal of Language and Literature Studies 2020.19 (June)

Social responsibility poster designs on 'Prevent language pollution, prefer Turkish words'/ Ç. Gümüş (pp. 192-203)




RumeliDE Dil ve Edebiyat Araştırmaları Dergisi 2020.19 (Haziran)/ 203

'Dil kirliliğini engelle Türkçe kelimeleri tercih et' konulu soysal sorumluluk afiş tasarımları / Ç. Gümüş (192-203. s.)

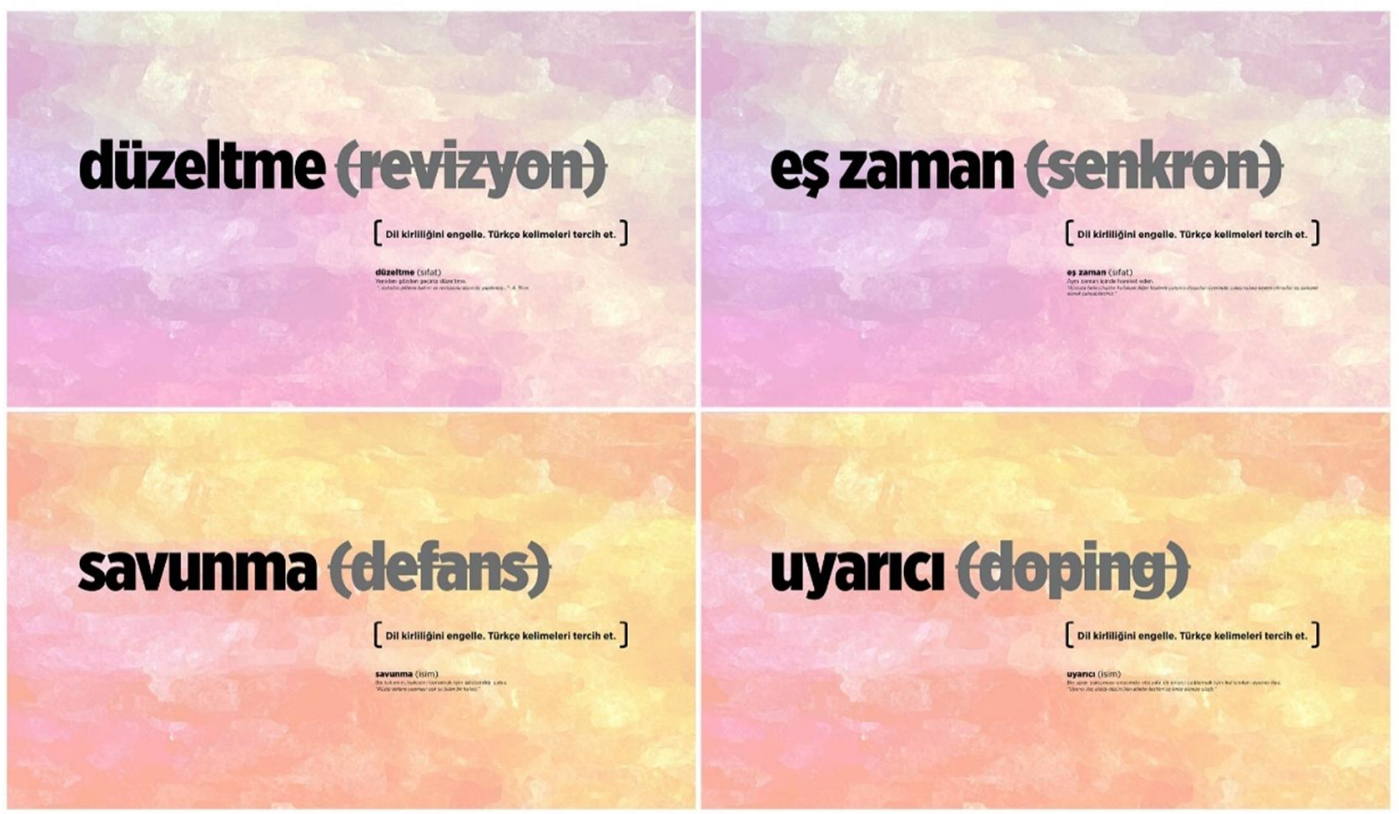

